\title{
EVALUATION OF SELECTED LEGUME COVER CROPS FOR BIOMASS PRODUCTION, DRY SEASON SURVIVAL AND SOIL FERTILITY IMPROVEMENT IN A MOIST SAVANNA LOCATION IN NIGERIA
}

\author{
Y. A. ABAYOMI, O. FADAYOMI, J. O. BABATOLA and G. TIAN ${ }^{1}$ \\ Department of Crop Production, University of Ilorin, P.M.B. 1515, Kwara State, Nigeria \\ ${ }^{1}$ Soil Fertility Unit, RCMD, International Institute of Tropical Agriculture (IITA), \\ P.M.B. 5320, Ibadan, Nigeria
}

(Received 9 June, 1999; accepted 9 July, 2001)

\begin{abstract}
The growth and development of eighteen legume cover crop species were evaluated at the University of Ilorin Teaching and Research Farm $\left(8^{\circ} 29^{\prime} \mathrm{N}, 4^{\circ} 35^{\circ} \mathrm{E}\right)$ in the southern Guinea savanna zone during the $1993-1996$ cropping seasons. Field establishment, ground cover, above ground biomass production, and seed yields of the legume species were monitored during each cropping season. This was followed by an in-situ bioassay to determine the residual effect of the sown legume on maize (Zea mays L.) production in the absence of added nitrogen at the end of one season of legume growth each year. The results show that field establishment was generally poor $(<30 \%)$ for most of the legume species, particularly the small seeded species. This resulted in a significant correlation between seed size and percent germination $(r=0.89)$. Similarly, seed production was poor in most of the species with the exception of Mucuna pruriens, Cajanus cajan and Crotalaria ochroleuca. On the other hand, majority of the legume species gave satisfactory ground cover, biomass production, and $\mathrm{N}$ contribution to the succeeding non-legume crop. Using the rank summation index, the order of adaptation of the legume species to the study location on the basis of their ground cover, biomass production, seed yield, dry season survival and $\mathrm{N}$ contribution to the soil was as follows: Cajanus cajan $>$ Aeschynomene histrix $>$ Stylosanthes guianensis $>$ S. scabra $>$ Crotalaria ochroleuca $>$ C. verrucosa $>$ Clitorea tarnatea $>$ S. hamata $>$ Pseudovigna argentea $>$ Centrosema pascuorum $>$ Pueraria phaseoloides $>$ Lablab purpureus $>$ Psophocarpus palustris $>$ Chamaecrista rotundifolia $>$ Macroptilium atropurpureum. Management practices aimed at ameliorating the poor field establishment and seed yield are suggested.
\end{abstract}

Key Words: Field establishment, Guinea savanna, legumes, soil fertility improvement

\section{RÉSUMÉ}

Pendant les saisons de recolte de 1993 à 1996, le Centre de Formation et de Recherche de l'Université de Ilorin $\left(8^{\circ} 29^{\prime \prime} \mathrm{N}, 4^{\circ} 35^{\prime \prime} \mathrm{E}\right)$ a mesuré l'accroissement et évalué le développement de dix-huit espèces de culture de plante au sud de la savane de Guinee. A chaque saison culturale, l'établissement de terrain, le couvert du sol, la production de la biomasse en surface, et le rendement de graines des differentes espèces des plantes ont été suivis de près. Un bio-essai en place a suivi ces études afin de déterminer les effets résiduaires des plantes semées sur la production de maïs (Zea mays L.) sans addition de nitrogene a la fin d'une saison annuelle de culture de plantes. Les résultats montrent que l'établissement de terrain était généralement pauvre $(<30 \%)$ pour la plupart de espèces et particulièrement pour les petites espèces semées. Ceci a conduit a une forte correlation entre la taille de la graine et le pourcentage de germination $(\mathrm{r}=0.89)$. De même la production de graines était pauvre pour la plupart de espèces avec l'exception de Mucuna pruriens, Cajanus cajan et Crotalaria ochroleuca. D'autre part la majorité 
des espèces de plantes a donné des résultats satisfaisants pour le couvert du sol, la production biomasse, et les contributions $\mathrm{N}$ pour les cultures suivantes non légumineuses. En utilisant la base d'addition indexée ci-après, l'ordre d'adaptation des especes de plante (avec l'étude de l'emplacement basée sur le sol couvert, la production biomasse, le rendement de graines, la survie de saison sèche et la contribution $\mathrm{N}$ à la terre) est le suivant Cajanus cajan $>$ Aeschynomene histrix $>$ Stylosanthes guianensis $>$ S. scabra $>$ Crotalaria ochroleuca $>$ C. verrucosa, $>$ Clitorea tarnatea $>S$. hamata $>$ Pseudovigna argentea $>$ Centrosema pascuorum $>$ Peuraria phaseoloides $>$ Lablab purpureus $>$ Psophocarpus palustris $>$ Chamaecrista rotundifolia $>$ Macroptilium atropurpureum. Les pratiques de gestion visant à l'amélioration des pauvres établissements en champs et le rendement en graines sont suggérées.

Mots Cles: Établissement de terrain, Guinea savanna, légumés, amélioration de la fertilite du sol

\section{INTRODUCTION}

Land degradation and declining soil fertility leading todecreasing total agricultural productivity is a problem in sub-Saharan Africa (Okigbo, 1985; Lal, 1989). Integration of leguminous cover crops into the existing cropping system has been reported to offer the potential for overcoming this problem. Legumes have the potential to improve soil fertility thereby boosting subsequent crop yield (Mohammed-Saleem, 1986; Maccoll, 1990; Tarawali, 1991). Legumes offer other benefits such as maintenance and improvement of soil physical properties, providing ground cover to reduce soil erosion, increasing soil organic matter, cation exchange capacity, microbial activity and reduction of soil temperature (Vallis and Gardner, 1984; Mohammed-Saleem, 1986; Mulongoy and Kang, 1986; Tarawali et al., 1987). Another potential benefit of legume cover crops is their ability to suppress weeds (Akobundu, 1980, 1982) and nematodes (Sharma et al., 1982).

Legumes can be integrated into the existing cropping system either as cover crops, live mulch, fodder or food crops through planted fallow or multiple cropping system (Kang, 1992). Although grain legumes such as cowpea (Vigna unguiculata L. Walp) and groundnut (Arachis hypogeae L.) have played important roles in food and animal feed, there is little likelihood that a significant portion of the $\mathrm{N}$ requirement of succeeding nonlegume crops can be met from the residue of grain legumes (Mughogino et al., 1982). Hence, there has been renewed interest in the use of leguminous cover crop, due to low capital base of farmers to purchase inorganic fertiliser as well as concern for the environment.
There are several species of tropical legumes, but only a few have been studied and mostly for their potential as fodder crops (Tarawali et al., 1987; Tarawali and Mohammed-Saleem, 1994). Lal et al. (1979) reported the beneficial effects of growing Psophocarpus palustris on soil structure, while Mucuna pruriens var utilis has been found useful in improving the physiological properties of compacted alfisols (Hullugale et al., 1986). In the northern territory of Australia, Bridge et al. (1983) reported that growing Stylosanthes hamata increased macro porosity and infiltration rate of the soil. On the other hand, Ile et al. (1996) have suggested that growing of Mucuna pruriens var utilis as a relay cover crop may reduce the need to apply synthetic $\mathrm{N}$-fertiliser.

The most important task in this effort is to identify the most relevant legume species for integration into the farming systems. The present study therefore formed part of a series of studies initiated by the International Institute for Tropical Agriculture (IITA) in collaboration with the Nigerian Agricultural Research System (NARS) to evaluate and characterise some selected legume cover crop species for adaptation in the moist savanna zones of Nigeria. The broad objective of the study was to evaluate the potential of the selected legume species for establishment, growth characteristics, biomass and seed production, soil fertility improvement and weed suppression.

\section{MATERIALS AND METHODS}

The trials were located on the University of Ilorin Teaching and Research Farm at Bolorunduro $\left(8^{\circ}\right.$ $29^{\prime} \mathrm{N}, 4^{\circ} 35^{\prime} \mathrm{E}$ ) in the southern Guinea savanna ecological zone of Nigeria. The area is 
characterised by a bimodal rainfall pattern with peaks in June and September and a dry spell between mid- July and August. The average annual rainfall for the area is $1000-1240 \mathrm{~mm}$. The soil of the farm has been classified as Typic Haplustalf.

Thirteen legume species (Table 1) were compared during 1993, while 18 legume types were evaluated during 1994 and 1995. During 1993 one control was included, but there were two control plots per replicate during the 1994 and 1995 seasons. In 1993, the legume species were planted into rows that were $1000 \mathrm{~mm}$ apart, while the inter row spacing was reduced to $750 \mathrm{~mm}$ in the two subsequent years. Cajanus cajan, Lablab purpureus, Mucuna pruriens and Psophocarpus palustris were planted at intra- row spacing of $250 \mathrm{~mm}$, while the other legume species were drilled with sand and lightly covered with soil in 1993. In 1994, the above legume species as well as Centrosema brasilianum, C. pascuorum, Clitorea tarnatea, Macroptilium atropurpureum, and Pseudovigna argentea were planted at the intra-row spacing of $250 \mathrm{~mm}$, while others were drilled. In 1995, all the legume species were planted at regular intra-row spacing of $250 \mathrm{~mm}$ for the medium to large seeded legume species and $750 \mathrm{~mm}$ for the small seeded species. Plots measuring $12 \mathrm{~m}$ x $10 \mathrm{~m}$, were used. In 1993, 14 of such plots were grouped together to make a replicate while in both 1994 and 1995 trials, there were 20 plots per replicate. The plots were arranged as a set of randomised complete blocks with four replicates.

Each year the trial sites were disc- ploughed and harrowed. The legume plots were hoe-weeded four weeks after planting (WAP) in 1993 and 3 and 7 WAP in 1994 and between 5 and 11 and 13 WAP in 1995. Phosphorus and potassium fertilisers, were applied at the rates of $15 \mathrm{~kg} \mathrm{P}_{2} \mathrm{O}_{5}$ ha $^{-1}$ as single super phosphate and $30 \mathrm{~kg} \mathrm{~K}_{2} \mathrm{O}$ $\mathrm{ha}^{-1}$ as potassium chloride to the legume plots as side dressing 7 WAP each year. One of the control plots within each replicate was similarly weeded and fertilised as above in 1994 and 1995 , while the other control plots for these years were left unweeded and unfertilised. At the beginning of the 1994, 1995 and 1996 cropping seasons, the legume plots planted the previous year (1993, 1994 and 1995, respectively) were weeded by hand pulling. When the rains had become well established, the surviving legume plants (if any) in one third of the plot $(4 \mathrm{~m} \times 10 \mathrm{~m})$ were slashed, cut into small pieces, and left on the soil surface. Maize (Zea mays L.) var DMRSR-Y was

TABLE 1. Legumes evaluated in this study with an indication of their growth habit, seed size (mg per seed) and percent germination during the three seasons of study (1993-1995)

\begin{tabular}{|c|c|c|c|c|c|c|}
\hline \multirow[t]{2}{*}{ Legume species } & \multirow[t]{2}{*}{ Type } & \multirow{2}{*}{$\begin{array}{l}\text { Seed size } \\
\quad(\mathrm{mg})\end{array}$} & \multicolumn{4}{|c|}{ Percent germination } \\
\hline & & & 1993 & 1994 & 1995 & Mean \\
\hline Aeschynomene histrix & Semi erect & 1.2 & $6 c \mathrm{ce}$ & $9 e$ & 15def & 10 \\
\hline Cajanus cajan & Erect & 108.2 & $33 b$ & $26 c d$ & $52 c$ & 37 \\
\hline Centrosema brasilianum & Trailing & 30.6 & $5 \mathrm{cde}$ & $36 \mathrm{~cd}$ & $72 b$ & 38 \\
\hline Centrosema pascuorum & Trailing & 20.8 & $6 c d e$ & $34 c$ & $55 c$ & 32 \\
\hline Chamaecrista rotundifolia & Trailing & 3.9 & 6 cde & $26 c d$ & 9f & 19 \\
\hline${ }^{\star}$ Clitorea tarnatea & Semi erect & 46.7 & * & $17 \mathrm{de}$ & 21def & 19 \\
\hline Crotalaria ochroleuca & Erect & 15.5 & $8 c d e$ & $14 \mathrm{e}$ & 23def & 15 \\
\hline Crotalaria verrucosa & Semi erect & 17.7 & $1 e$ & $8 e$ & $19 \mathrm{de}$ & 9 \\
\hline Lablab purpureus & Trailing & 289.6 & $63 a$ & $63 b$ & $53 c$ & 60 \\
\hline *Macroptilium atropurpureum & Trailing & 12.6 & $\star$ & $13 e$ & 31d & 22 \\
\hline Mucuna pruriens (black seeded) & Trailing & 780.3 & $15 c$ & $79 a$ & $98 a$ & 64 \\
\hline "Mucuna pruriens (white seeded) & Trailing & 763.8 & 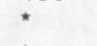 & $81 a$ & $92 a$ & 86 \\
\hline *Stylosanthes guianensis & Semi erect & 1.6 & $\star$ & $12 e$ & 20def & 16 \\
\hline Stylosanthes hamata & Semi erect & 3.4 & $4 \mathrm{de}$ & $9 e$ & $9 f$ & 7 \\
\hline *Stylosanthes scabra & Semi erect & 1.7 & * & $8 e$ & 29de & 18 \\
\hline Pseudovigna argentea & Trailing & 46.8 & 6 cde & $14 e$ & 14 ef & 12 \\
\hline Psophocarpus palustris & Trailing & 93.5 & $27 b$ & $27 c d$ & 30de & 28 \\
\hline
\end{tabular}

Not planted in 1993. Figures followed by the same letter(s) in a column are not significantly different at 5 percent probability level (LSD) 
subsequently planted in these mini plots, as test crops for monitoring the residual effects of the legumes on soil nitrogen supply. At the same time the control plots in the previous year's planting were each divided into three $4 \mathrm{~m} \times 10 \mathrm{~m}$ subplots, planted with maize and each subplot was fertilised at the rate of 0,30 or $60 \mathrm{~kg} \mathrm{~N} \mathrm{ha}^{-1}$. Germination percent was established for each replicate plot.

Phenological observations including onset of trailing or branching, onset of flowering, onset of podding, pod filling time and seed shedding were recorded on weekly basis starting from 4 WAP. Legume ground cover was evaluated using the beaded string method 14 WAP in 1993, and 4, 8, 12 and $20 \mathrm{WAP}$ in the subsequent years. A nylon string, knotted at $10 \mathrm{~cm}$ intervals, was laid across the diagonal of the whole plots $(8 \mathrm{~m} \times 10 \mathrm{~m})$. The number of knots touching a live legume plant was expressed as a percentage of the total number of knots laid in the plot. This was done for the two diagonals and means were computed. Samples of the above ground legume growth were harvested from randomly located $1 \mathrm{~m}^{2}$ quadrants in the destructive sampling area $(4 \mathrm{~m} \mathrm{x} 10 \mathrm{~m})$ to estimate biomass production 10,12 and 14 WAP in the first year, but modified to $8,12,16$ and 20 WAP in the subsequent years. Legume regrowth during the second year of establishment was assessed as ground cover by visual observation about 15 months after planting (MAP) while biomass production was determined $16 \mathrm{MAP}$ for each legume species. Seeds were harvested from $1 \mathrm{~m}^{2}$ within the whole plot, making sure that most of the shed seeds were collected. Ripe maize ears were harvested, sun-dried, threshed and weighed to give grain yield per plot. Samples of the threshed grain were oven dried at $65^{\circ} \mathrm{C}$ to determine the moisture content for evaluating grain weight at $14 \%$ moisture content. Data collected were subjected to analysis of variance and separation of means was by the Least Significant Difference test at $5 \%$ probability level. Specific performance was evaluated using the Rank Summation Index (RSI) (Abayomi and Saliu, 1997).

\section{RESULTS}

Field establishment, phenology, diseases and pest incidence of legume species. Field germination was generally less than $30 \%$ in most species except Mucuna pruriens, Lablab, Centrosema brasilianum, C. pascuorum and Cajanus cajan (Table1). A three-year average germination of $86 \%$ was recorded for Mucuna pruriens (white seeded) with a seed weight of $763.1 \mathrm{mg}$, while the lowest germination of $7.2 \%$ was obtained with Stylosanthes hamata with a seed weight of $3.4 \mathrm{mg}$.

The three-year means of the phenological data are presented in Table 2. Onset of trailing started earliest in two varieties of Mucuna pruriens (14 DAP), and latest in Macroptilium atropurpureum (46 DAP). Branching in erect and semi erect species was earliest in Cajanus cajan (32 DAP) and latest in Crotalaria verrucosa (46 DAP). Flowering was earliest in Chamaecrista rotundifolia (37 DAP), relatively early in Clitoria tartanea (39 DAP) and M. atropurpureum (48 DAP), latest in Pseudovigna argentea and Pueraria phaseoloides (119 DAP). Podding followed a similar trend with pod formation occurring first in Chamaecrista rotundifolia (51 DAP), followed by $M$. atropurpureum (56 DAP) and Clitorea tartanea (60 DAP). However, pod filling time was shortest with Centrosema pascuorum (19 days) followed by Sylosanthes guianensis, S. hamata and Pseudovigna argentea (21 days). Duration of pod filling was longest with Clitorea tarnatea (42 days), Crotalaria verrucosa (40 days), $M$. pruriens (32-39 days) and Psophocarpus palustris (35 days). Although some legume species showed slight wilt symptoms caused by Rhizoctania and Bacterium spp. during the peak of rains in the first year of study, there were no severe diseases or pests incidence. The soil population of nematodes in general and Meloidogyne incoginita in particular were reduced by Stylosanthes spp. and Crotalaria spp., and these observations were further confirmed by the results of the root gall index (Data not shown).

\section{Ground cover, biomass and seed production.} Percent ground cover during the year of establishment was highest with the two varieties of Mucuna pruriens, which had almost perfect ground coverage 12 WAP (Table 3 ). Percent ground coverage was also high for Centrosema pascuorum $(76 \%)$, Lablab purpureus $(84 \%)$ and Psophocarpus palustris (61\%) 12 WAP. Ground coverage during the year of establishment was 
TABLE 2. Average days from planting to phenological events in legume species

\begin{tabular}{|c|c|c|c|c|c|}
\hline \multirow[t]{2}{*}{ Legume species } & \multirow{2}{*}{$\begin{array}{l}\text { Branching/ } \\
\text { Trailing } \\
\text { (DAP) }\end{array}$} & \multicolumn{2}{|c|}{ Fowering } & \multicolumn{2}{|c|}{ Podding } \\
\hline & & $\begin{array}{l}\text { onset } \\
\text { (DAP) }\end{array}$ & $\begin{array}{c}50 \% \\
\text { (DAP) }\end{array}$ & $\begin{array}{l}\text { onset } \\
\text { (DAP) }\end{array}$ & $\begin{array}{l}\text { pod filling } \\
\text { (days) }\end{array}$ \\
\hline Aeschynomene histrix & 45B & 96 & 119 & 110 & 24 \\
\hline Cajanus cajan & 32B & 112 & 140 & 149 & 23 \\
\hline Centrosema brasilianum & 39T & 73 & 87 & 85 & 32 \\
\hline Centrosema pascuorum & 32T & 54 & 70 & 89 & 19 \\
\hline Chamaecrista rotundifolia & 32B & 37 & 63 & 51 & 24 \\
\hline Clitorea tarnatea & 32T & 39 & 64 & 60 & 42 \\
\hline Crotalaria ochroleuca & $39 \mathrm{~B}$ & 68 & 79 & 84 & 23 \\
\hline Crotalaria verrucosa & $46 B$ & 68 & 82 & 84 & 40 \\
\hline Lablab purpureus & $25 \mathrm{~T}$ & 100 & 117 & 124 & 26 \\
\hline Macroptilium atropurpureum & $46 \mathrm{~T}$ & 49 & 70 & 56 & 32 \\
\hline Mucuna pruriens (Black seeded) & $14 \mathrm{~T}$ & 112 & 132 & 126 & 37 \\
\hline Mucuna pruriens (white seeded) & $14 \mathrm{~T}$ & 84 & 95 & 98 & 39 \\
\hline Stylosanthes guianensis & 39B & 105 & 118 & 133 & 21 \\
\hline Stylosanthes hamata & $39 B$ & 56 & 72 & 98 & 21 \\
\hline Stylosanthes scabra & 39B & 75 & 91 & 84 & 34 \\
\hline Pseudovigna argentea & $14 \mathrm{~T}$ & 119 & 152 & 154 & 21 \\
\hline Psophocarpus palustris & 32T & 96 & 106 & 110 & 35 \\
\hline
\end{tabular}

Data are means of three years. $T=$ Trailing, $B=$ Branching, $D A P=$ days after planting

TABLE 3. Percent ground cover of spreading legume species 12 weeks after planting (*14 in 1993) in the year of establishment and 15 months after planting during the second year of establishment

\begin{tabular}{|c|c|c|c|c|c|c|c|c|}
\hline \multirow[t]{2}{*}{ Legume species } & \multicolumn{4}{|c|}{ Percent ground cover establishment year } & \multicolumn{4}{|c|}{ Second year of establishment } \\
\hline & 1993 & 1994 & 1995 & Mean & 1994 & 1995 & 1996 & Mean \\
\hline Aeschynomene histrix & $25 e$ & $15 e$ & $14 \mathrm{~g}$ & 18 & $76 a b$ & $64 a b$ & $98 a$ & 79 \\
\hline Centrosema brasilianum & $49 d$ & $28 d$ & $44 c$ & 40 & $79 a b$ & $57 a b c$ & $94 \mathrm{ab}$ & 77 \\
\hline Centrosema pascuorum & $54 \mathrm{~cd}$ & $88 b$ & $85 b$ & 76 & Od & 11 ef & $25 \theta$ & 12 \\
\hline Chamaecrista rotundifolia & $50 d$ & $57 c$ & $35 \mathrm{~cd}$ & 47 & $49 c$ & $33 c d e$ & $77 \mathrm{bc}$ & 53 \\
\hline Clitorea tamatea & na & $37 d$ & 20 ef & 28 & na & $15 \mathrm{ef}$ & $55 \mathrm{~d}$ & 35 \\
\hline Crotalaria verrucosa & $5 f$ & $12 \theta$ & $26 \mathrm{de}$ & 14 & $9 d$ & $8 e f$ & $73 c$ & 30 \\
\hline Lablab purpureus & $71 b$ & $98 a b$ & $77 b$ & 84 & Od & $14 \mathrm{ef}$ & $3 f$ & 6 \\
\hline Macroptilium atropurpureum & na & $36 \mathrm{~d}$ & 20ef & 28 & na & $16 \mathrm{ef}$ & $50 \mathrm{~d}$ & 34 \\
\hline Mucuna pruriens (black) & $91 \mathrm{a}$ & $99 a$ & $99 a$ & 96 & $1 d$ & $28 \mathrm{cde}$ & of & 10 \\
\hline Mucuna pruriens (white) & na & $100 a$ & $100 a$ & 100 & na & $46 \mathrm{bcd}$ & $5 f$ & 17 \\
\hline Stylosanthes guianensis & na & $7 e f$ & $9 \mathrm{gh}$ & 8 & na & $81 a$ & $96 a$ & 89 \\
\hline S. hamata & $25 e$ & $15 c$ & $14 \mathrm{fg}$ & 18 & $54 c$ & $54 \mathrm{bc}$ & $55 d$ & 54 \\
\hline S. scabra & na & $3 f$ & $4 h$ & 3 & na & $46 \mathrm{bcd}$ & $45 d$ & 46 \\
\hline Pseudovigna argentea & $47 d$ & $48 c$ & $34 \mathrm{~cd}$ & 43 & $86 a$ & $60 a b$ & $98 a$ & 81 \\
\hline Psophocarpus palustris & $69 b c$ & $83 b$ & $33 d$ & 62 & $10 d$ & $9 e f$ & $5 f$ & 8 \\
\hline Pueraria phaseoloides & $47 d$ & $16 c$ & $22 c-f$ & 28 & $65 \mathrm{bc}$ & $69 a b$ & $95 \mathrm{a}$ & 76 \\
\hline SED & 8.3 & 7.2 & 7.9 & & 7.9 & 10.2 & 8.8 & \\
\hline
\end{tabular}

na $=$ data not available

Figures followed by the same letter(s) in a column are not significantly different by LSD test at 5 percent probability level 
minimal with the three species of Stylosanthes and Aeschynomene histrix, all of which, however had between $46 \%$ to $79 \%$ ground coverage during the second year of establishment (Table 3 ). The second year ground cover was also high for Centrosema brasilianum (77\%), Pseudovigna argentea $(81 \%)$, Cajanus cajan $(89 \%)$ and Pueraria phaseoloides (76\%). Unlike the first year, however, legume ground cover was very poor for Mucuna pruriens, Labalab purpureus, Crotalaria ochroleuca, Psophocarpus palustris and Centrosema pascuorum, all of which showed poor dry season survival/ regrowth from shed seeds during the second year.

Cajanus cajan produced the highest dry matter (DM) per unit area during the year of establishment, in all the three years of this study, with best result in 1994 (Fig.1a). These values
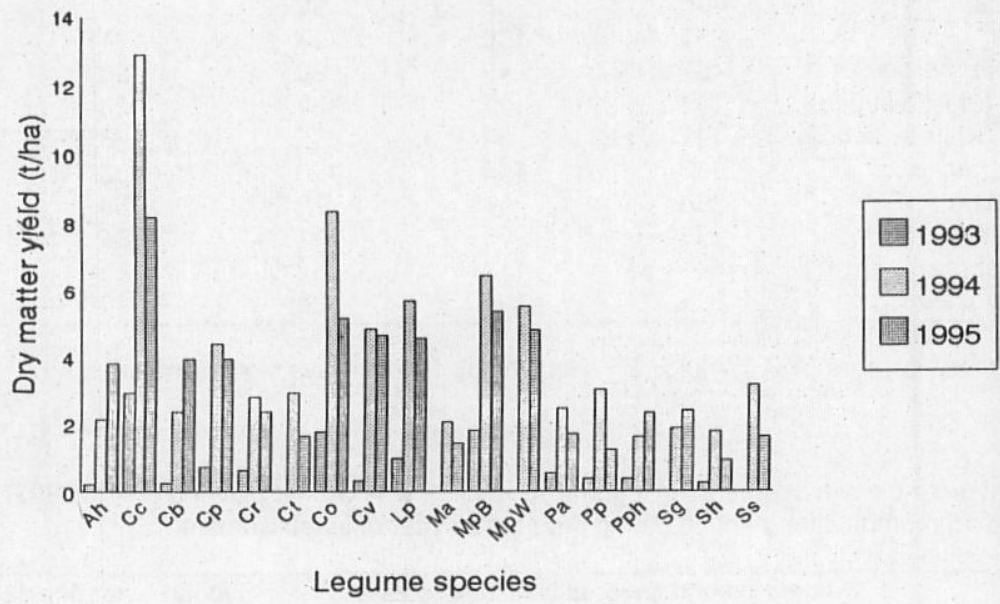

Legume species

b

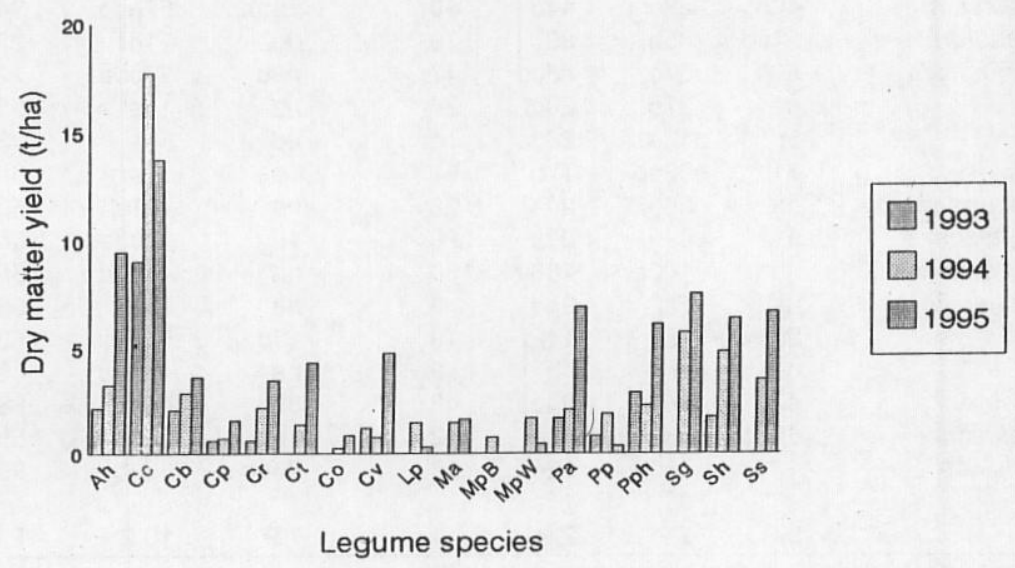

Figure 1. Above ground biomass yield of legume species during (a) the establishment year and (b) second year of growth during the three years of study.

$\mathrm{Ah}=$ Aeschynomene histrix, $\mathrm{Cc}=$ Cajanus cajan, $\mathrm{Cb}=$ Centrosema brasiianum, $\mathrm{Cp}=$ Centrosema pascuoru, $\mathrm{Cr}=$ Chamaecrista rotunditolia, $\mathrm{Ct}=$ Clitorea tarnatea, $\mathrm{Co}=$ Crotalaria ochroleuca, $\mathrm{Cv}=$ Crotalaria verrucosa, $\mathrm{Lp}=\mathrm{Lablab}$ purpureus, $\mathrm{Ma}=$ Macroptilium atropurpureum, $\mathrm{MpB}=$ Bucuna pruriens (black seed) $\mathrm{MpW}=$ Mucuna pruriens (White seeded), $\mathrm{Pa}=$ Pseudovigna argentea, $\mathrm{Pp}=P$ sophocarpus palustris, $\mathrm{Pph}=$ Pueraria phasedoides, $\mathrm{Sg}=$ Stylosanthes guianensis, $\mathrm{Sh}=$ Stylosanthes hamata, $\mathrm{Ss}=$ Stylosanthes scabra. 
were significantly higher than in the other species $(\mathrm{P}<0.05)$. This was followed by Mucuna pruriens (white seeded), Crotalaria ochroleuca, M. pruriens (black seeded) which had similar.DM yield. Of the 18 species evaluated, only six had a three year mean DM less than $2.0 \mathrm{t} \mathrm{ha}^{-1}$, with the lowest production from Stylosanthes hamata.

In the second year of establishment, the above ground DM was again highest with Cajanus cajan and the value was $67 \%$ higher than in the first year (Fig.1b) and lowest with Mucuna spp. which had a 95\% decrease in DM yields compared to the year of establishment. DM production during the second year of establishment showed a reversal with that of the first year for Stylosanthes spp., Aeschynomene histrix, Pueraria phaseoloides and Centosema brasilianum, which had significantly higher DM yields than most other species during the year of establishment. Mucuna pruriens (white seeded) had the highest seed production averaged across three seasons (Fig. 2). This was followed by yields in Cajanus cajan, M. pruriens ( black seeded), Centosema pascuorum, Lablab purpureus and Clitorea tarnatea in that order.
Persistence and residual $\mathrm{N}$ contribution to soil. Of the 18 legume species evaluated in this study, Mucuna pruriens, Lablab purpureus, Centrosema pascuorum, Psophocarpus palustris and Crotalaria ochroleuca showed no dry season survival and very little re-establishment from the shed seeds (Table 4). The remaining 12 species persisted by surviving the dry season and / or regrowing from shed seeds, and continued growing once the rains returned. Averaged over three years, excellent dry season survival and /or second year re-establishment from shed seeds were obtained from Stylosanthes scabra, S. guianensis, Cajanus cajan, Pseudovigna argentea and Aeschynomene histrix. Survival / reestablishment was also good (between $80 \%$ to 98\%) for Clitorea tarnatea, S. hamata and Pueraria phaseoloides and fair (57\% to $70 \%)$ for Macroptilium atropurpureum, Chamaecrista rotundifolia and Crotalaria verrucosa.

Maize grain yield following one year of legume growth show that yields from those legume plots with high biomass production were higher than those of the unfertilised control plots and similar

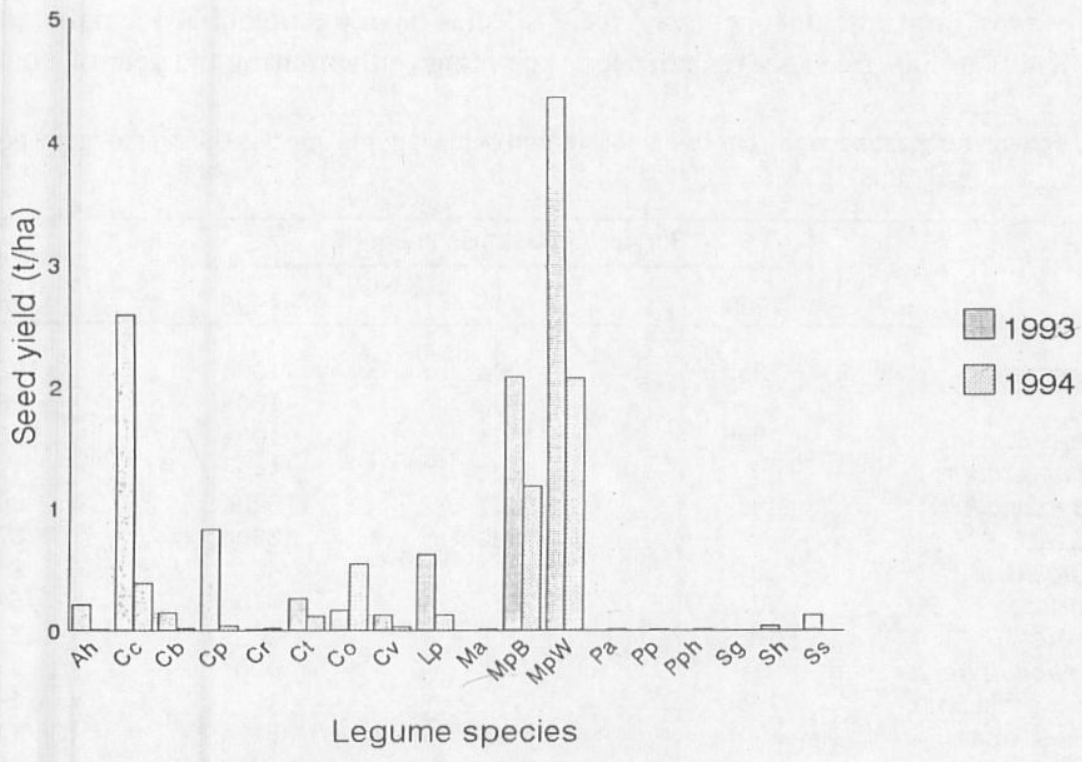

Figure 2. Seed yield in evaluated legume species during two cropping season.

$\mathrm{Ah}=$ Aeschynomene histrix, $\mathrm{Cc}=$ Cajanus cajan, $\mathrm{Cb}=$ Centrosema brasiianum, $\mathrm{Cp}=$ Centrosema pascuoru, $\mathrm{Cr}=$ Chamaecrista rotunditolia, $\mathrm{Ct}=$ Clitorea tarnatea, $\mathrm{Co}=$ Crotalaria ochroleuca, $\mathrm{Cv}=$ Crotalaria verrucosa, $\mathrm{Lp}=\mathrm{Lablab}$ purpureus, $\mathrm{Ma}=$ Macroptilium atropurpureum, $\mathrm{MpB}=$ Bucuna pruriens (black seed) $\mathrm{MpW}=$ Mucuna pruriens (White seeded), $\mathrm{Pa}=$ Pseudovigna argentea, $\mathrm{Pp}=$ Psophocarpus palustris, $\mathrm{Pph}=$ Pueraria phasedoides, $\mathrm{Sg}=$ Stylosanthes guianensis, $\mathrm{Sh}=$ Stylosanthes hamata, $\mathrm{Ss}=$ Stylosanthes scabra. 
to those of control plots that received various rates of $\mathrm{N}$ fertiliser in the two cropping seasons of assessment (Fig. 3). Grain yields due to legume were generally higher in 1995 than in 1996, while response to $\mathrm{N}$ application in control plots were better in 1996 than in 1995. Averaged over the two seasons, grain yields were highest in plots preceded by Stylosanthes guianensis and the value was higher than yields obtained from control plot fertilised with $60 \mathrm{~kg} \mathrm{~N}^{-1}$ by $43 \%$. This was followed by grain yields from Cajanus cajan, Aeschynomene histrix, Crotalaria ochroleuca and Psophocarpus palustris plots which had similar yields to those of the control plots with an inorganic $\mathrm{N}$ application of $60 \mathrm{~kg} \mathrm{~N} \mathrm{ha}^{-1}$.

\section{DISCUSSION}

Ecological adaptation is an important factor in legume integration into the farming system (Anon, 1993). The present study has demonstrated that some of the legume cover crop species evaluated are well adapted to the prevailing conditions in the study location which are typical conditions in the southern Guinea savanna ecological zone of Nigeria. However, crop establishment may be problematic (if not carefully managed) as indicated by the generally poor 3-year average germination $(<30 \%)$ in most species except Mucuna spp., Lablab purpureus, Centrosema brasilianum, $C$. pascuorum and Cajanus cajan (Table1). A significant correlation $(r=0.89)$ between seed size and percent germination showed the dependence of field establishment on seed size of the legume species. This might be an important factor affecting early ground cover and weed suppression in these species (Abayomi and Fadayomi, 1995). The problem of crop establishment in evaluated species, however, can be minimised by careful management practices including seed scarification, planting when rains are well established, and early weed control.

Even though leguminous cover crops have been shown to contribute $\mathrm{N}$ to the soil for subsequent crops (Peters et al., 1994a, b; Tarawali, 1991, 1995; Ile et al., 1996), it has, however, been pointed out that the major requirement to be met is whether there are legume species which grow rapidly to cover the soil during the rainy season and persist as live or dead mulch during the dry season (Carsky, 1993). The results of the present study have shown that some of the evaluated species have the potential for rapid soil surface coverage either during the year of establishment

TABLE 4. Dry season survival/second year re-establishment of the legume species during the study period (19931995)

\begin{tabular}{|c|c|c|c|c|}
\hline \multirow[t]{2}{*}{ Legume species } & \multicolumn{3}{|c|}{ Survival/ re-establishment (\%) } & \multirow[b]{2}{*}{ Mean } \\
\hline & 1993 & 1994 & 1995 & \\
\hline Aeschynomene histrix & $78 a b$ & $100 a$ & $100 a$ & 92 \\
\hline Cajanus cajan & $93 a b$ & $100 a$ & $100 \mathrm{a}$ & 98 \\
\hline Centrosema brasilianum & $79 a b$ & $100 a$ & $100 a$ & 93 \\
\hline Centrosema pascuorum & od & $43 d$ & $14 \mathrm{e}$ & 19 \\
\hline Chamaecrista rotundifolia & $49 c$ & $68 c$ & $92 \mathrm{bc}$ & 69 \\
\hline Clitorea tarnatea & - & $85 a b c$ & $89 \mathrm{bc}$ & 87 \\
\hline Crotalaria ochroleuca & $1 d$ & $2 f$ & $4 f$ & 2 \\
\hline Crotalaria verrucosa & $9 d$ & $73 c$ & $91 \mathrm{bc}$ & 57 \\
\hline Lablab purpureus & Od & 6ef & $2 f$ & 3 \\
\hline Macroptilium atropurpureum & - & $90 \mathrm{ab}$ & $50 d$ & 71 \\
\hline Mucuna pruriens (black) & $1.0 \mathrm{~d}$ & $3 f$ & if & 1 \\
\hline Mucuna pruriens (white) & - & 15 ef & $6 e f$ & 11 \\
\hline Stylosanthes guianensis & - & $98 a$ & $100 a$ & 99 \\
\hline S. hamata & $53 c$ & $90 a b$ & $99 a b$ & 81 \\
\hline S. scabra & - & $100 a$ & $100 a$ & 100 \\
\hline Pseudovigna argentea & $86 a$ & $95 \mathrm{a}$ & $100 a$ & 94 \\
\hline Psophocarpus palustris & $10 d$ & $23 e$ & If & 11 \\
\hline
\end{tabular}

Figures followed by the same letter(s) in a column are not significantly different by LSD test at 5 percent probability level 
or the subsequent years. Following crop establishment, Mucuna pruriens and Lablab purpureus grew faster than the other species, covering ground rapidly. These results agree well with the reports of Carsky (1993) in Cameroon and Marilla et al. (1992) in Brazil. Ground cover during the year of establishment was also good with Centrosemapascuorum and Psophocarpus palustris but were relatively slower and poorer in Stylosanthes spp. and Aeschynomene histrix. The report of Marilla et al. (1992) also showed that Stylosanthes spp. were among the slowest growers of the evaluated 52 species in their study.

Although anthracnose is a major disease of Stylosanthes spp. (Skerman etal., 1988; Tarawali, 1994), S. hamata and its accessions have been reported to show tolerance to this disease in the northern Guinea savanna zone of Nigeria (Tarawali, 1985). The present study found no evidence of anthracnose in species of Stylosanthes in particular and the legume species evaluated in general. Stylosanthes spp. and Crotalaria spp. appeared not to support nematode populations, and the root gall index suggests that these species are resistant to the root-knot nematode (Meloidogyne incognita). This is important when selecting legume for integration into food crops that are susceptible to nematode infection.

Of the most important traits usually sought in herbaceous legumes, especially for use as forage crop, is persistence (Peters et al., 1994a, b; Tarawali, 1995). Of the 18 species evaluated, 12 persisted to the second year to varying degrees, although with little or no growth during the dry season. However, with the onset of the rains during the second year, they grew fast and covered the ground rapidly especially Stylosanthes guianenses, Aeschynomene histrix, Centrosema brasilianum, Pseudovigna argentea, Cajanus cajan and Pueraria phaseoloides. Excellent persistence has been reported for $C$. brasilianum (Peters et al., 1994a), Stylosanthes guianensis, S. hamata and Aeschynomene histrix (Peters et al., 1994b). Most of the other legume species (Mucuna spp., Lablab purpureus, Crotalaria ochroleuca and Centrosema pascuorum) died before the end of the dry season. The observation for $C$. pascuorum is consistent with the report of Peters et al. (1994a) for the northern Guinea savanna zone, while those for Mucuna spp. and Crotalaria ochroleuca are in contrast to an earlier report which showed that Mucuna and Crotalaria species survived dry season in Brazil (Anon, 1992).

For green manure legumes to contribute meaningfully to the soil $\mathrm{N}$ requirements of a succeeding crop, Marilla et al. (1992) suggested that it must produce at least $2000 \mathrm{~kg} \mathrm{ha}^{-1}$ of above ground dry biomass or $40 \mathrm{~kg} \mathrm{~N}^{-1}$ for the incorporation into the soil so that a $50 \%$ recovery of the biomass $\mathrm{N}$ would affect the succeeding crop's yield. In this study, Centrosema brasilianum, C. pascuorum, Clitorea, Lablab purpureus, Stylosanthes guianensis, S. scabra, Mucuna pruriens (both white and black seeded), Crotolaria ochroleuca, Cajanus cajan and Aeschynomene histrix had biomass production well above the suggested minimum in the year of establishment (Fig.1a). Second year growth also resulted in biomass production in excess of 2000 $\mathrm{kg} \mathrm{ha}^{-1}$ in Stylosanthes spp., Cajanus cajan, Aeschynomene histrix and Pueraria phaseoloides (Fig.1b). Most of the legume species evaluated in the present study have the potential to contribute more $\mathrm{N}$ than the minimum required to produce any real effect on subsequent crops.

However, in spite of the large above ground biomass production recorded for most species in this study, maize grain yield following legumes were lower than $1000 \mathrm{~kg} \mathrm{ha}^{-1}$ ( Fig. 3). Nevertheless, these yields were comparable to those obtained by Tarawali (1994) at the International Livestock Center for Africa (ILCA), Kaduna, Nigeria. The increased yield due to the previous legume residues over no legume suggest that there were residual effects of $\mathrm{N}$ from the legumes, but it was insufficient for optimum grain yield. The overall lower yield was probably due to the fact that the legumes were not incorporated but were left as surface residues. Lathwell (1990) observed that surface application of legume residues without incorporation may result in large losses of $\mathrm{N}$, probably because of ammonia volatilisation from decomposing plant material. Palm (1988) had earlier reported that only $15 \%$ of the $\mathrm{N}$ in surface applied legume cuttings was recovered by a rice crop to which the cutting had been applied.

More importantly, there were variations in the potential of legumes to contribute residual $\mathrm{N}$ to succeeding non-legume crops. Thus, maize grain 
yield was highest in plot preceded by Stylosanthes guianensis $\left(907.2 \mathrm{~kg} \mathrm{ha}^{-1}\right)$, followed by yields from plots of Cajanus cajan $\left(746.1 \mathrm{~kg} \mathrm{ha}^{-1}\right)$ and Crotalaria ochroleuca $\left(699.5 \mathrm{~kg} \mathrm{ha}^{-1}\right)$, all of which were higher than yields from the control plots given $60 \mathrm{~kg} \mathrm{~N} \mathrm{ha}^{-1}$ inorganic fertiliser $(635.8$ $\mathrm{kg} \mathrm{ha}^{-1}$ ). These results suggest that $\mathrm{N}$ contribution by these species may have been greater than $60 \mathrm{~kg}$ $\mathrm{N} \mathrm{ha}{ }^{-1}$. Plots of other species including Centrosema brasilianum, Clitorea tarnatea, Stylosanthes scabra, Psophocarpus palustris, Mucuna pruriens and Crotolaria verrucosa had maize grain yields higher than that of the control given $30 \mathrm{~kg} \mathrm{~N} \mathrm{ha}^{-1}$ inorganic fertiliser. Contrastingly, plots of Centrosema pascuorum, Chamaecrista rotundifolia, Lablab purpureus, Macroptilium atropurpureum, Stylosanthes hamata and Pueraria phaseoloides had maze grain yields lower than those of the control fertilised at $30 \mathrm{~kg} \mathrm{~N} \mathrm{ha}^{-1}$. These results are consistence with the report of Tarawali and Mohammed-Saleem (1994) who showed that the benefit of a legume to subsequent crops was a function of species used.

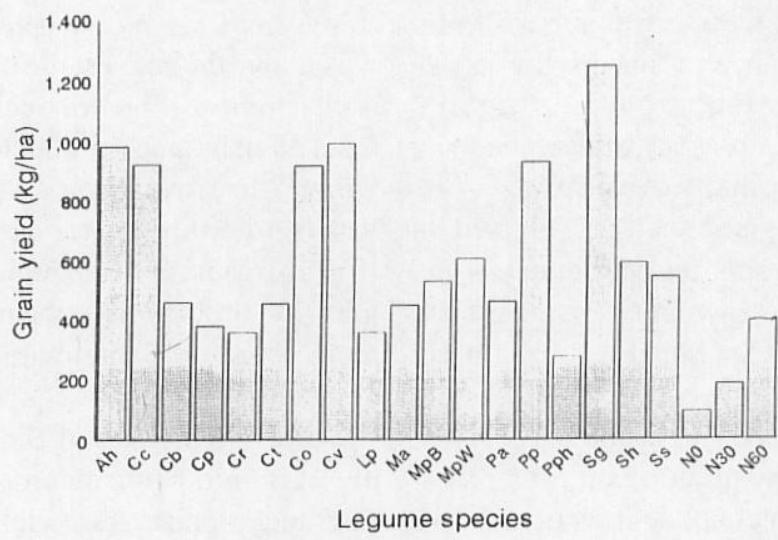

1996

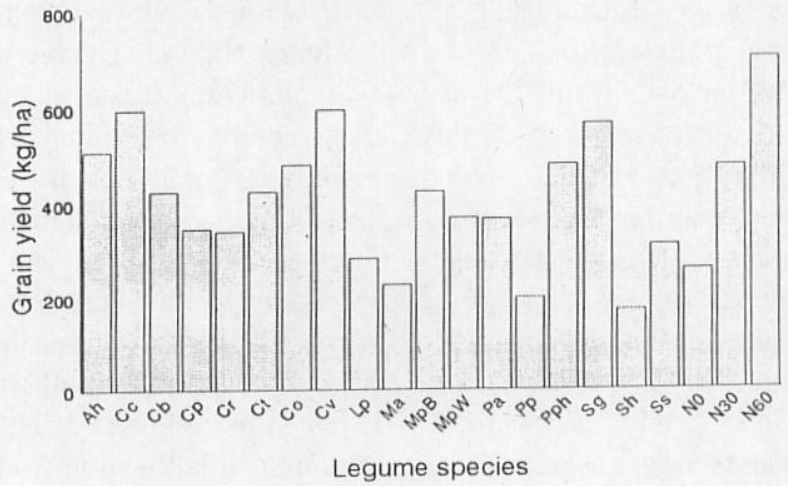

Figure 3. Maize grain yield in plots preceeded by different legume species and control plots given different levels of $\mathrm{N}$ fertiliser.

$\mathrm{Ah}=$ Aeschynomene histrix, $\mathrm{Cc}=$ Cajanus cajan, $\mathrm{Cb}=$ Centrosema brasiianum, $\mathrm{Cp}=$ Centrosema pascuoru, $\mathrm{Cr}=$ Chamaecrista rotunditolia, $\mathrm{Ct}=$ Clitorea tarnatea, $\mathrm{Co}=$ Crotalaria ochroleuca, $\mathrm{Cv}=$ Crotalaria verrucosa, $\mathrm{Lp}=\mathrm{Lablab}$ purpureus, $\mathrm{Ma}=$ Macroptilium atropurpureum, $\mathrm{MpB}=$ Bucuna pruriens (black seed) $\mathrm{MpW}=$ Mucuna pruriens (White seeded), $\mathrm{Pa}=$ Pseudovigna argentea, $\mathrm{Pp}=$ Psophocarpus palustris, $\mathrm{Pph}=$ Pueraria phasedoides, $\mathrm{Sg}=$ Stylosanthes guianensis, $\mathrm{Sh}=$ Stylosanthes hamata, $\mathrm{Ss}=$ Stylosanthes scabra, NO =0 kg ha-1 N, N30 = Control $+30 \mathrm{~kg} \mathrm{ha}^{-1} \mathrm{~N}, \mathrm{~N} 60=$ Control $+60 \mathrm{~kg} \mathrm{ha}^{-1}$. 
TABLE 5. Species ranking and rank summation index* (RSI) showing the performance of legume species at the trial location

\begin{tabular}{|c|c|c|c|c|c|c|c|c|c|}
\hline \multirow[t]{2}{*}{ Legume species } & \multicolumn{2}{|c|}{ Ground cover } & \multicolumn{2}{|c|}{ Biomass yield } & \multirow{2}{*}{$\begin{array}{l}\text { Seed } \\
\text { yield }\end{array}$} & \multirow{2}{*}{$\begin{array}{c}\text { Residual } \mathrm{F} \\
\mathrm{N} \\
\text { contribution }\end{array}$} & \multirow{2}{*}{ Persistence } & \multirow[t]{2}{*}{$\mathrm{RSI}$} & \multirow{2}{*}{$\begin{array}{l}\text { Final } \\
\text { rank }\end{array}$} \\
\hline & Year 1 & Year 2 & Year 1 & Year 2 & & & & & \\
\hline Aeschynomene histrix & 15 & 4 & 12 & 4 & 8 & 3 & 1 & 47 & 2 \\
\hline Cajanus cajan & 5 & 1 & 1 & 1 & 2 & 2 & 5 & 17 & 1 \\
\hline Centrosema brasilianum & 10 & 5 & 10 & 8 & 10 & 9 & 9 & 61 & 5 \\
\hline Centrosema pascuorum & 4 & 14 & 7 & 15 & 5 & 15 & 16 & 76 & 13 \\
\hline Chamaecrista rotundifolia & 18 & 8 & 13 & 11 & 13 & 16 & 13 & 82 & 17 \\
\hline Clitorea tarnatea & 11 & 10 & 9 & 9 & 7 & 10 & 14 & 70 & 10 \\
\hline Crotalaria ochroleuca & 7 & 18 & 3 & 17 & 4 & 4 & 11 & 64 & 7 \\
\hline Crotalaria verrucosa & 16 & 12 & 6 & 10 & 11 & 6 & 6 & 67 & 8 \\
\hline Lablab purpureus & 3 & 17 & 5 & 16 & 6 & 18 & 15 & 80 & 15 \\
\hline Macroptilium atropurpureum & 12 & 11 & 14 & 12 & 14 & 17 & 12 & 92 & 18 \\
\hline Mucuna pruriens (black) & 2 & 15 & 4 & 18 & 3 & 8 & 17 & 67 & 8 \\
\hline Mucuna pruriens (white) & 1 & 13 & 2 & 13 & 1 & 7 & 18 & 55 & 4 \\
\hline Stylosanthes guianensis & 17 & 1 & 11 & 2 & 18 & 1 & 1 & 51 & 3 \\
\hline S. hamata & 14 & 7 & 18 & 5 & 12 & 13 & 1 & 70 & 10 \\
\hline S. scabra & 18 & 9 & 8 & 3 & 9 & 11 & 4 & 62 & 6 \\
\hline Pseudovigna argentea & 9 & 3 & 16 & 7 & 16 & 12 & 8 & 71 & 12 \\
\hline Psophocarpus palustris & 6 & 16 & 15 & 14 & 15 & 5 & 10 & 81 & 16 \\
\hline
\end{tabular}

* The smaller the figure, the better the performance

The results of this study have demonstrated that legumes can enhance soil fertility thereby boosting subsequent crop yields. However, in order for the selected species to be introduced into the farming systems, seeds must be available. Although seed yields recorded in this study were generally low (Fig. 2), it has been observed that under careful management Stylosanthes hamata var Verano can yield $>500 \mathrm{~kg} \mathrm{ha}^{-1}$ (Kachelriess and Tarawali, 1994). Similar yields could be anticipated from the species evaluated.

The overall ranking of the legume species evaluate in this study (Table 5) in terms of potential for ground cover, biomass production, seed yield, persistence and residual $\mathrm{N}$ contribution to soil show that Cajanus cajan >Aeschynomene histrix $>$ Stylosanthes guianensis > Mucuma pruriens (white seeded) > Centrosema brasilianum > Stylosanthes scabra $>$ Crotalaria ochroleuca $>$ M. pruriens (black seeded) $>$ Crotalariaverrucosa $>$ Clitorea tarnatea $>$ S. hamata $>$. Pseudovigna argentea $>$ Centrosema pascuorum $>$ Pueraria phaseoloides > Lablab purpureus > Psophocarpus palustris > Chamaecrita rotundifolia $>$ Macroptilium atropurpureum .

\section{ACKNOWLEDGEMENT}

We are grateful to Drs. I.O. Akobundu and B.T. Kang, formerly of IITA, for stimulating the interest of the authors in this project and the Moist Savanna Programme in the RCMD of IITA for providing financial and material support for the execution of this project. Dr. B.A.O. Ibikunle gratefully provided the information for the description of the trial location.

\section{REFERENCES}

Abayomi, Y.A. and Fadayomi, R.O. (1995). Agronomy report. In: Legume Characterization in the moist savanna zone: Report of 1994 activities at Ilorin in the southern Guinea savanna zone. Fadayomi, R.O. (Ed.), pp.1122.

Abayomi, Y.A. and Saliu, L.O. 1997. Emergence and seedling vigour responses to simulated sub-optimal moisture conditions in twelve open-pollinated maize (Zea mays L.) varieties. Bioscience Research Communications 9:2128. 
Akobundu, I. O. 1980. Live mulch: A new approach in weed control and crop production in the tropics. In: Proceeding of the 1980 British Crop Protection Conference. pp. 377 -382 .

Akobundu, I. O. 1982. Live mulch crop production in the tropics.In: World Crops. pp. 125-145.

Allen, O. N. and Allen, E.K. 1981. The Leguminosae. University of Wisconsin Press, Wisconsin, U.S.A.

Annonymous, 1992. Screening legumes for dryseason survival. In: Legume Green Manure: Dry season survival and the effect on succeeding maize crops. Soil Management CRSP Bulletin No. 92-04. pp. 9-13.

Annonymous, 1993. Improvement of soil fertility and weed suppression through legume-based technologies. Collaborative group in maize based system research (COMBS). IITA Research Guide 48, International Institute of Tropical Agriculture, Ibadan, Nigeria. 52 pp.

Bridge, P. T., Mott, J. J., Inter, W.H. and Hewtigan, R. J. 1983. Improvement in soil structure resulting from sown pasture on degraded area in the dry savanna woodland of northern Australian. Australian Journal of Agricultural Research 31:83 -90.

Carsky, R. J. 1993. Screening multiple use cover crops for the semi-arid zone. Technical Note No. 13 TLU, Manova. 10 pp.

El-Swaify, S. A., Holdenhaver, W.C. and Lo, A. (eds). 1985. Soil erosion and conservation. Volume based on the international Conference on soil erosion conservation, January 16-22, 1983. Honolulu, Hawaii.

Ile, E., Hamadina, N.K., Zufa, K. and Henst, J. 1996. Note on effect of Mucuna pruriens var utilis crop on the growth of maize (Zea mays) on arid soils in Southern Nigeria. Field Crop Research 18:135-140.

Jensen, H.G.P. 1993. Ex-cute profitably of animal traction investment in semi-arid sub-Saharan Africa. Evidence from Niger and Nigeria. Agricultural System 43:333-349.

Kalchelriess, S. and Tarawali, S.A. 1994. ILCA's efforts towards ite production of Stylosanthes seed in Nigeria. In: Stylosanthes as a forage and fallow crop. Kaduna, Nigeria. October, 1992. (International Livestock Centre for Africa, Addis Ababa).
Kang, B.T. 1992. Potentials of legumes for soil fertility improvement in the humid and subhumid tropics. In: Collaborative Group on Maize-based system Research (COMBS). 1992 Report of the 2nd Workshop, Kumasi, Ghana, June, 1990. West African Farming System Research Network (WAFSR/ RESPAO), Ougadougou, Burkina Faso, and International Institute of Tropical Agriculture(IITA), Ibadan, Nigeria.

Lal, R. 1989. Agroforestry systems and soil surface management of a tropical Alfisol II. Changes in soil chemical properties. Agroforestry System 8:113-132.

Lal, R., Hullugalle, N.R. and Terkuile, CH. H. 1979. Changes in properties of all Alfisol produced by various cover crop. Tropsoils. Soil Science 127:337-382.

Lathwell, D.J. 1990. Legume green manure. Principles for management based on recent research. Tropsoils Technical Bulletin, No. 90-01.

MacColl, D. 1990. Studies on maize (Zea mays, L.) at Bunda, Malawi. III. Yield in rotation with pasture legumes. Experimental Agriculture 26:263-271.

Marilla, L. B., Jao, R. S., Dinas, P., Jose, V.S.R., Manod, R.R., Walter, S.C., David, B. and Douglas, J. L. 1992. Legume green manures: Dry season survival and the effect on the succeeding maize crops. Soil Management CRSP Bulletin 92-04.

Mohammed-Saleem, M. A. 1986. The ecology, vegetation and land use of subhumid Nigeria. In: Livestock system research in Nigeria's sub-humidzone. Proceedings of secondILCA/ NAPRI Symposium held in Kaduna, Nigeria. 29 October -2 Nov. 1984 . Von Kaufmann, R., Chater, S. and Belnch, R. (Eds.). ILCA(International Livestock Centre for Africa), Addis Ababa, Ethiopia.

Mohammed-Saleem, M. A. and Otsyina, R. M. 1986. Grain yields and the nitrogen contribution following Stylosanthes pasture in the Nigeria sub-humid zone. Experimental Agriculture 22:207- 214.

Mohammed-Saleem, M. A., Suleiman, H. and Otsyina, R. M. 1986. Fodder Banks: for pastoralist or farmers. In: Potential of forage legumes in farming systems of sub-saharan 
Africa. Hague, I., Jutzi, S. and Nestle, P. J. H. (Eds), pp. 420- 437. Proceeding of workshop held at ILCA, Addis Ababa, Ethiopia, September 16-19, 1985. ILCA(International Livestock Centre for Africa), Addis Ababa, Ethiopia.

Mulongoy, K. and Kang, B. T. 1986. The role of potential forage legumes in alley cropping, live mulch and rotational systems in humid and sub-humid tropical Africa. In:Potential of forage legumes in farming systems of subsaharan Africa. Hague, I., Jutzi, S. and Nestle, P.J.H. (Eds.), pp. 212-231. Proceeding of workshop held at ILCA, Addis Ababa, Ethiopia, September 16-19, 1985. ILCA (International Livestock Centre for Africa), Addis Ababa, Ethiopia.

Mughoho, S.K., Awali, J., Lowendorf, H.S. and Lathwell, A.T. 1982. The effects of fertilizer nitrogen and Rhizobium inoculation on yield of subsequent crops of maize. In: Biological nitrogen fixation for tropical agriculture. Graham, P.H. and Harri, S.C. (Eds.), pp. 297301. Proceedings of a workshop held at CIAT, March 9-13, 1981, Cali, Colombia.

Myers, R.J.K. 1976. Nitrogen accretion and other soil changes in Tundall clay loam townsuile stylo/grass pasture. Australian Journal of Experimental Agriculture and Animal Husbandry 16:94-98.

Okigbo, B.N. 1985.Land use productive potentials of Africa savanna. In: Ecology and Management of the World's savanna. Tothill, J.C. andMoh.J.J.(Eds), pp.95-106. Australian Academy of Science, Camberra, Australia/ CAB (Commonwealth Agriculture Bureau), Farham Royal Bucks, U.K.

Palm, C.A. 1988. Mulch quality and nitrogen dynamics in an alley cropping system in the Peruvian Amazon. Ph.D. Thesis, North Carolina State University, Raleigh.

Peters, M., Tarawali, S.A. and Alkamper, J. 1994a. Evaluation of tropical legumes for fodder banks in sub-humid Nigeria 1: Accession of Centrosema brasilianum, C. pascuorum,
Chamaecrista rotundifolia and Stylosanthes hamata. Tropical Grassland 28:65-73.

Peters, M., Tarawali, S.A. and Alkamper, J. 1994b. Evaluation of tropical legumes for fodder banks in sub-humid Nigeria 2: Accession of Aeschynomene histrix, Centrosema acutifolium, C. pascuorum, Stylosanthes guianensis, and Stylosanthes hamata. Tropical Grassland 28:74-79.

Sharma, F.D., Pereira, J. and Resk, D.V.S. 1982. Efficience de adubos verde no control de nematodes associadies a soja nos cerrdos. Boletin de Pes̀isa 13, EMBRAPA-CPAC Planeltina, Brazil.

Skerman, P.J., Cameron, D.G. and Riveros, F. 1988. Tropical Forage Legumes. $2^{\text {nd }}$ edition. FAO Plant Protection and Production Series 2. FAO, Rome.

Tarawali, G. 1991. Residual effect of Stylosanthes fodder banks on grain yields of maize. Tropical Grassland 25:26-31.

Tarawali, S.A. 1994. Evaluating selected forage legumes for livestock and crop production in the sub-humid zone of Nigeria. Australian Journal of Experimental Agriculture 34:5560.

Tarawali, S.A. 1995. Evaluation of Stylosanthes hamata $(\mathrm{L})$ Tuab accessions for livestock and crop enterprises in sub-humid Nigeria. Australian Journal of Experimental Agriculture 35:375 - 379.

Tarawali, G., Mohammed-Saleem, M.A. and Von Kaufmann, R. 1987. Comparision of labour requirements for cropping maize on land previously used for Stylosanthes fodder banks and an adjacent fallow in the sub-humid zone of Nigeria. ILCA Bulletin 26: 36-39. ILCA (International Livestock Centre for Africa), Addis Ababa, Ethiopia.

Vallis, J. and Gardner, C.J.1984. Nitrogen inputs into agricultural systems by Stylosanthes. In: The biology and agronomy of Stylosanthes. Stance, H.M. and Edye, L.A.(Eds.), pp. 359380. Academy Press, Australia. 